\title{
EXISTENCE OF SUFISM IN THE MIDST OF MULTICULTURAL AND GLOBAL COMMUNITIES \\ (Prospects and Problems of the Development)
}

\author{
A. Suradi ${ }^{1}$ and Nurfitria Dewi ${ }^{2}$ \\ ${ }^{1}$ Institut Agama Islam Negeri Bengkulu, Indonesia \\ ${ }^{2}$ Sekolah Tinggi Ilmu Tarbiyah Payakumbuh, Indonesia \\ suradi@iainbengkulu.ac.id \\ Article history:
}

Submitted: 02-07-2018 | Revised: 24-10-2018 | Accepted: 30-06-2019

\begin{abstract}
:
This article aims to examine the prospects and problems of developing Sufism in the multicultural and globalization era. This research is a library research. In the era of multiculturalism and globalization that civilization, science and technology have influenced all aspects of life, including the touch of spiritual values. In this case, ideally, science and technology in Islam must be able to deliver someone to further increase the faith and piety to Allah. The advancement of science in this multicultural and global era must be useful to recognize the creation, majesty and greatness of God, so that it can encourage people to get closer to Him. But in reality, modernization only satisfies the outer needs, even though humans will remain nervous as long as their inner and divine needs are not fulfilled. It is hoped that the values of Sufism, which is spiritual conditioning, can fill the emptiness of the human soul so that the obedience of the people in carrying out the rules of Shari' $a$ and the appreciation of religion at the level of essence and Sufism does not slip into the abyss of shirk and khurafat.
\end{abstract}

Keywords: Sufisme, Multicultural Era, Globalization

\begin{abstract}
Abstrak:
Artikel ini bertujuan untuk mengkaji tentang bagaimana prospek dan problem pengembangan ajaran sufisme di era multikultural dan globalisasi. Penelitian ini merupakan penelitian pustaka. Di era multikultural dan globalisasi ini bahwa peradaban, ilmu pengetahuan, dan teknologi telah mempengaruhi dalam segala aspek kehidupan, tidak terkecuali dari sentuhan nilai-nilai spiritual. Dalam hal ini idealnya, ilmu pengetahuan dan teknologi dalam Islam harus mampu menghantarkan seseorang untuk lebih meningkatkan keimanan dan ketakwaan kepada Allah. Kemajuan ilmu pengetahuan di era multikultural dan global ini harus bermanfaat untuk mengenal ciptaan, keagungan dan kebesaran Allah, sehingga dapat mendorong manusia untuk semakin mendekatkan diri kepada-Nya. Namun secara realitas, modernisasi hanya memuaskan kebutuhan lahiriah saja, padahal manusia akan tetap gelisah selama kebutuhan batiniah dan Ilahiah tidak terpenuhi. Diharapkan nilai-nilai tasawufyang merupakan penyejuk rohani dapat
\end{abstract}


mengisi kehampaan jiwa manusia, sehingga kepatuhan umat dalam melaksanakan aturan syariat serta penghayatan agama pada tingkat hakikat dan makrifat tidak tergelincir ke jurang syirik dan khurafat.

Kata Kunci: Ajaran Sufisme, Era Multikultural, Globalisasi

\section{Introduction}

Modernity as a global phenomenon is the most influential factor, which is how the theorists of modernism state, against the existence of tradition and religion. These two elements will disappear along with the success achieved by the secularism project that takes place globally. However, since the modernist movement, which was represented among others by the concept of a secular state, a nation state, and democracy, was considered to have failed to fulfill its promises, tradition and religion, in general, became media to express their disappointment with failures and consequences. by modernism. In this situation of incompetence, Islamic movements today that propagate the idea of "returning to authentic Islam" can be a good example for analyzing contemporary relations between modernity and religion. ${ }^{1}$

In this multicultural and globalization era, the teachings of Sufism are very quiet and lonely in the Islamic world, including in Indonesia. Many Muslim researchers have concluded that there are two prominent factors that have led to the collapse of Sufism in the Islamic world: Sufism experts have lost faith in the Islamic community, because many of them are too deviant from the true teachings of Islam; for example, no longer performing prayers because they have reached the level of ma'rifat, as well as other Islamic Shari'a. In addition, the progress of European nations with non-Muslim religions has dominated all Muslim-majority countries. In this multicultural and globalization era, many Muslims themselves

${ }^{1}$ Achmad Ubaedillah, "Sufi Islam and the nation state: Darul Arkam movement in the post Suharto era of Indonesia", Indonesian Journal of Islam and Muslim Societies 5, no. 1 (2015): 80 . think more practically and are useful to the public in real terms (pragmatism). ${ }^{2}$

The progress of science and technology of human inventions that provide all facilities for convenience also has an impact on various psychological problems for humans themselves. Modern society is now greatly favoring science and technology, while religious understanding based on revelation is often left behind and the society lives in a secular state. They tend to pursue material life and hedonic lifestyle rather than thinking of religion which is considered not giving any role in their lives.

People have lost their vision of the Divine, and they have blunt visions of the reality of life. The advances that have taken place have penetrated in various aspects of life: social, economy, culture, or politics. This condition requires individuals to adapt to changes that occur quickly and surely. Even though in reality, not all individuals are able to do it so that what happens is that humans save many problems. For humans, this kind of life is felt in urban areas that compete with each other in all fields. The condition forces each individual to adapt quickly although not everyone can afford it. As a result, individuals appear to hold various psychological and physical problems, thus an effective way to find a solution is needed.

In the history of community development, Sufism is an equally controversial dimension of Islam. Its nature and existence are often misunderstood and underestimated. Theologically the teachings of Sufism by some circles, especially the modernist-oriented groups, are seen as teachings that do not originate from Islamic

${ }^{2}$ A.Qadri Azizy. Melawan Globalisasi-Reinterpretasi Ajaran Islam (Yogyakarta: Pustaka Pelajar, 2003), 174. 
teachings so that the believers can become musyrik. He is considered teaching that contains tahayul, bid'ah and khurafat. Socially, Sufism that teaches ascetic life is an obstacle to the development and progress of the times.

The development of Islamic models of Sufism is indeed a development that is not born just like that. The birth of Islamic understanding is a tension that is quite complicated. Sufism is a very complex spirituality. In this understanding, there is moral, emotional, cognitive and speculative. The beginning of the Sufi movement was a moral movement as a method for self-improvement. The movement is to realize Islamic religious values in full. But the subsequent development of the Sufi movement was a variety of additions to become an escalating movement. ${ }^{3}$

Presumably, this is more specific in the Sufism of the multicultural and globalization era as a new form that occurs in the midst of modern society. However, it seems that the challenge of Sufism is the actual form of the religious style of modern society in the multicultural and global era. If people are not careful, or they are wrong in teaching and its application, this will bring a form of forgery of Sufism. Or even more extreme, Sufism in the multicultural era and globalization that come into contact with the Sufistic style are only taking the spirit that is not intact from conventional Sufism known so far. If we understand the Sufis style, as if it only leads to the world of Sufism, we do not enter into the realm of Sufism in total.

Speaking of solutions, there is now a tendency for Muslim communities to take part in spiritual activities (Sufism). Sufism as the core of Islamic teachings emerged by providing solutions and therapies for human problems by bringing closer to Allah the Creator. Sufism's opportunity to deal with psychological illnesses for all human problems is increasingly widespread in

${ }^{3}$ Saliyo, "Mencari Makna Hidup dengan Jalan Sufi di Era Modern", Esoterik: Jurnal Akhlak dan Tasawuf 2, no. 1 (2016). Accessed http://dx.doi.org/10.21043/esoterik.v2i1. this modern era. Therefore, the author tries to review the existence of Sufism in the era of multiculturalism and globalization, in terms of the prospects and problems of its development.

\section{The Current Sufism}

The current condition of globalization is actually overtaken by thoughts based on the wisdom that pours out substantial, universal, and integral thinking through emancipatory, moralist, and spiritual pathways, namely an enrichment of the educational process which is based on the supreme values of Sufism with the aim of social praxis. In Western literature, Sufi or Sufism is often called Islamic Sufism. It is the way for personal experience of Divine Love through which God blesses humans and he includes the experience of extras which are remembered by mystics. Modern European scholars regard Sufism as a separate category in Islam, and they call it the term Sufism. This English term (as well as its equivalent in French and German), using the end of the word "ism" gives the impression that Sufism is a school of thought or ideology which is seen by many scholars as an element added to Islam that is legal and firm. ${ }^{4}$

The Orientalists believe that in fact any mystical expression in Islamic culture is actually taken from outside sources, generally Christian, Yoga, and Buddhist. Therefore, Sufism is a term that is often seen with a positive image by Orientalists because they understand that Sufism is against Islam. In fact, Sufism is a conception of knowledge that emphasizes spirituality as a method for achieving happiness and perfection in human life. Because it is related to the spiritual dimension, Sufism is more concerned with aspects of human life that are esoteric and spiritual which involves the perception of the heart and mind over the divine reality that is sacred and absolute.

It should be noted that Sufism in the definition is the way needed by someone to know the

\footnotetext{
${ }^{4}$ Annemarie Schimmel, Dimensi Mistik Dalam Islam (Jakarta: Pustaka Firdaus, 2002), 52.
} 
behavior of lust and the traits of lust, both bad and praiseworthy. Therefore, the position of Sufism in Islam is considered a religion that is related to moral aspects which are the substance of Islam. Where philosophers, Sufism was born from one of the basic components of Islam, namely Faith, Islam, and Ihsan. If faith gave birth to theology (kalam), Islam gave birth to the science of shari'a, then Ihsan gave birth to the science of morals or Sufism. $^{5}$

The source of Sufism itself is based on:

1. Qur'anic Sources

There are two concepts taken from this term, namely maqam and things. Both are the most important parts that apply to all schools of Sufism. But they clearly distinguish between the two, where the maqam (level) is characterized by the establishment, while things (conditions) are easily marked as missing. The concept of maqam, such as mujahadah nafs, takwa, ascetic, thanksgiving, patience, poverty and love, all are based on alQur'ân. Likewise, with ahwal (circumstances) such as; khauf, raja', hazn, the dignity is taken from him.

2. The life and the moral of Rasulullah Shallallâhu 'alaihi wa sallam

The most important aspect based on the life of the Prophet was taken from two phases namely the pre-prophetic and post-prophetic phases. During pre-prophetic, Rasulullah was often alone doing uzlah in Hira' Cave. This is the forerunner of the Sufis or ascetics; the study of spiritual practice that is directly connected with the creator. Furthermore, after prophethood, the Prophet always used to live in a simple life, a lot of worship, almsgiving and so on. The moral virtues he taught really became a complete example for the Companions. This is what the Sufis hold in both the chapter and the beginning, all of

${ }^{5}$ M. Amin Syukur, Tasawuf Kontekstual Solusi Problem Manusia Modern (Yogyakarta: Pustaka, 2003), 112. which are accepted from the moral life of the Prophet.

\section{Life of Prophet's Companions}

Friends of Four are the main foundation in emulating moral virtues. Thusi once told, that in many ways, Sufis have taken many examples of Umar ra. such as patches in the clothes, rigidity, peace, and so on, likewise, with Abu Bakr, Usman and Ali. All forms of worship and nobility are taken from there. For this reason, they confidently develop the teachings that they are embracing as a form of truth.

\section{Asy'ariyah Teachings.}

We cannot let Asy'ariyah Teachings go, especially this Akhlaki or Sunni group. Every Sufism teachings that they develop, are always associated with the Asy'ariyah concepts as their control, with the intention that their teachings do not deviate from Islamic teachings. For this reason, it is very important to be escorted by the framework of Ash'ariyah. This is also because most of Akhlaki Sufis are from Sunni Asy'ariyah. ${ }^{6}$

Thus, the era of globalization should not kill religious spirituality. Because the empty and molting parts of inner values begin to flow through the coolness of Sufism longing. In this era of globalization, on the one hand, there is also a very worrying condition, in which there are teachers in several Islamic boarding schools and study assemblies in modern society, many of which are found to be mounting inner suffering. The progress of science and technology is accompanied by advances in mental care. Human's mind is experiencing rapid development, but human's heart should remain in a weak state, so humans need the support of mental strength.

${ }^{6}$ Abul Wafa' al-Ghanimi, Madkhal ilā Tașawwuf al-Islām, cet. III (Kairo: Darussaqafah Linasyr wattauzi’, 1983), 39-45. 
The above conditions can be explained that when a person faces a modern global era, and cannot deal with it, the person will do positive and negative things. When a person chooses in his mind to do a negative thing, the person will get worse in his life choices. For example, negative behaviors are drugs, immorality, violence, crime, theft, and robbery. The other side of someone who is able to control himself and can face the era above, the person will tend to do positive things. Such behaviors such as perseverance carry out religious spirituality, always draw closer to God, or do other positive things that can help others. ${ }^{7}$

When examined, the process of modernization and the flow of globalization do not kill religion; on the contrary, it leads people from a dead end to finally forced to seek the divine path. But in reality, it is known that modernization only satisfies external needs, even though humans will remain nervous as long as their inner and outer needs are not fulfilled. Thus, it can be understood that the values of Sufism in this era of globalization people experience anxiety and thirst for religious insight as an inner need. The values of Sufism which is a spiritual spring in filling the emptiness of the human soul with divine roots, it is expected that the adherence of Muslims to carry out the rules of Shari'a will be in line with enthusiasm to practice the tarekat, so that the appreciation of religion at the level of essence and slippage does not slip into the shirk and khurafat.

As mentioned by Nasution cited by Saliyo, ${ }^{8}$ the path taken by someone who takes the Sufi path is indeed not simple, because it is full of obstacles and challenges. To move from station one to another requires patience, perseverance and sincerity, in fact, the time is not also short. The first path is repentance that is the repentance of all the big and small sins, trying not to repeat it. Second, the way of life is zuhud, which is not bound to the sparkling life of the world. Third,

${ }^{7}$ Saliyo, 120.

${ }^{8}$ Ibid., 125. a Sufi must also have a patient nature, so as to be ridiculed, insulted is a test received by a Sufi. Insults must not be reciprocated accordingly, but are sufficiently left and prayed for to gain awareness. Fourth, a Sufi always trusts Allah in every step. Fifth, a Sufi is always pleased, that is, not angry and not hate in any circumstances, even a Sufi is always happy. The last station of a Sufi is always in a state of love for God. A person who loves God will always be meaningful in his life. ${ }^{9}$

With this description, it can be said that the experience of sufistic values will give birth to the meaning of life or psychological well-being for those who experience it. In other words, someone who is undergoing Sufism will find the meaning of his life, even though other people do not find it. The meaning of life possessed by someone who is undergoing Sufism is very important to protect himself from stress, his physical health, and fulfillment of his psychological needs. The term life meaning shows that someone who has the meaning of life of the person is committed to the concept, framework, and value. Someone who has the meaning of life will understand his life, try to achieve life goals, and will provide the fulfillment of the needs needed in accordance with the level of ability that is in him.

The realization of Sufistic doctrine is not by avoiding, rejecting and avoiding material struggles, but transcending and breaking through the materialistic boundaries of material dynamics. Sufistic behavior and lifestyle are techniques of human liberation from material traps when carrying out social, economic and political actions, as well as in religious ritual activities. That is the ethical basis of every Sufi practice that should seep into every human action in social, economic and political life and various scientific activities. The essence of such Sufi teachings is easily recognized in all the teachings of the divine religions. Based on sufistic ethics, someone is willing to help alleviate the suffering of others,

${ }_{9}^{9}$ Ahmad Bangun Nasution dan Rayani Hanum Siregar, Akhlak Tasawuf(Jakarta: PT.RajaGrafindo Persada, 2013), 83. 
even though they themselves face difficulties and suffering. The achievements of the social, economic and political life of Sufis are always directed towards achieving spiritual qualities, not only for social status, accumulation of wealth and personal power.

\section{The Prospect of Sufism in the Midst of Multicultural Society and Globalization}

The multicultural era and globalization that are increasingly widespread in the modern age have now brought human life to be more rational, hedonic and individualistic. The rapid development of industrialization and the economy has put these modern humans into ones who no longer have independent individuals; their lives have been regulated by the automation of all mechanical technology so that daily activities have been trapped by the tedious flow of routines. As a result, humans are no longer indifferent, if the role of religion becomes increasingly displaced by the interests of worldly material. ${ }^{10}$

Islam and its believers must not only be able to survive in all conditions in the multicultural and globalization era, but also must be able to play an active role. If the position of "survive" is likely to lead to isolation, closure and inferiority, and active position (effort to influence) will result in openness and superiority. At least the third possibility is accommodative, namely adjustments and acceptance of things as far as they can be tolerated. The need for Sufism is not only to restore spiritual values or be closer to God, but also useful in various fields of human life in the era of multiculturalism and globalization.

The concept of the modern era described above is very contrary to the statement of Sayyid Hossein Nasr, that science and art in Islam are based on the idea of monotheism, which is the

${ }^{10}$ Ahmad Suyuti, Percik-Percik Kesufian (Bandung: Penerbit Pustaka Hidayah, 2002), 3-5. core of al-Qur'ân. ${ }^{11}$ Thus according to Nasr, all science and technology in Islam with its diversity is inseparable from the oneness of Allah. Science and technology in Islam cannot be separated from the touch of spiritual values, because science and technology in Islam must be able to deliver someone to further increase the faith and piety of Allah. That would be clearer when viewed in terms of the intelligence of Sufistic thought.

Sufism's responsibility is not to escape from worldly life, as some people who disagree with Sufism accuse. But Sufism is an attempt to arm themselves with new spiritual values that will fortify themselves when facing materialistic and hedonistic life and life problems, and try to realize mental balance so that the ability to deal with these various problems arises in a manly manner.

Although in science Sufism discourse is not recognized because of its powerful nature, but its existence in the midst of society proves that Sufism is a separate part of a community's life; as a movement, religious belief, organization, networking and even healing or therapy. ${ }^{12}$ Thus, the presence of Sufism in the multicultural era and globalization can train people to have inner acumen and subtlety. Sufism will bring people to have an istiqamah soul, namely a soul that is always filled with divine values and one always has guidance in one's life.

Such circumstances cause people to remain steadfast, patient and not easily blown away by trials that will deflect the brink of destruction. That is a positive contribution that can be explored and developed from Sufism teachings. For this reason, Sufism must be one of the most important alternatives in overcoming the problems of people's lives in the era of multiculturalism and globalization. The teachings of Sufism need to

\footnotetext{
${ }^{11}$ Seyyed Hossein Nasr, Science and Civilization in Islam (USA: Harvard University Press, 1968). Accessed from https://scholar. google.co.id/citations?user=S9yBpOMAAAAJ\&hl.

${ }^{12}$ Moh. Soleh, Agama Sebagai Terapi (Yogyakarta: Pustaka Pelajar, 2005), 35.
} 
be injected into the whole concept of life, which includes knowledge, technology, economics, social, politics, and culture.

It should be noted that Sufism was recognized in history as having had a profound influence on the moral and spiritual life of Islam throughout thousands of years ago. During that period Sufism was so attached to the dynamics of the life of the wider community, not merely a small group that was exclusive and isolated from the outside world. So the presence of Sufism in the modern world is very necessary, in order to guide human beings to stay long and close to their Lord, and it can also be for people who were originally glamorous and who were happy to be ascetic.

The ultimate goal of Sufi teachings to be achieved by the adherents is to draw closer to Allah (taqarrub ila Allah) in order to achieve His pleasure, by mujahadah through the spiritual riyadhah and cleansing the soul (tazkiyah al$n a f s)$. Soul and body influence each other. If the soul is perfect and holy, the actions of the body will be good: decorated with morality which is blessed by Allah. Thus, Sufism brings people to live according to the actual rules of life in accordance with the concept of al-Qur'ân and al-Sunnah, such as simple life, not excessive, thankful, tawadhu', living by doing something in accordance.

The spiritual experience of a Sufi is analogous to the fact that it is like a mango taste: however someone explains the feeling of $d u k u$ to others, but if someone has never tried the taste of mango, we can be sure that he will not understand the true taste of mango. In other words, the spiritual experiences of the Sufis can be felt but cannot be revealed so that the messages and advice they write can be interpreted by the readers according to their reasoning ability to capture the message contained behind the text.

Studying Sufism brings tremendous benefits in this life, both individually, society, nation and country. If all people who insist on God willing, this earth will be safe from all conflicts and hostilities, because Sufism always carries universal messages that have nuances of coolness, peace, tranquility, love for others, even with nature, the environment and other creatures. The teachings of Sufism come through cross tribes, races, ethnicities and even religions. A Sufi, such as Ibn 'Arabî, highly respected religious pluralism. Thus, the concept of Sufism teachings is very tolerant, open and acceptable to all groups.

The people who practice the teachings of Sufism (the Sufis), their lives will feel more meaningful, beautiful, and full of simplicity in living this life, everything is lived with sincerity, gratitude, patience, qana'ah, and tawakkal over all the provisions set by God for himself, not complaining and not despairing, but always optimistic in navigating this life and everything is returned to God Almighty. Sufis are always able to capture messages and wisdom behind the reality that occurs in this world.

Sufis are very aware of who they are and how they are before God and they are able to master their passions, so that everything they do is always in the corridor of obedience, obedience and submission to Allah SWT. with full of pleasure, love and they were loved by God as well, even Allah invited them to a very beautiful banquet. " $O$ calm soul. Return to your Lord with a heart that is pleased and pleased by Him. Then enter into my class of servants, and enter into my heaven." 13 The people invited by God are certainly not just anyone but those who are invited are those who have reached the level (maqam) insan kamil (complete human) who within them have reflected the attributes of God.

Thus, multicultural and global conditions, thoughts that are based on the deepening of wisdom about thinking that are substantial, universal, and integral through emancipatory, moral, and spiritual pathways. Sufism is not a passive or apathetic attitude towards social reality, but plays a major role in realizing a spiritual revolution in society.

${ }^{13}$ Q.S. Al-Fajr (89): 27-30. 
In the midst of multicultural conditions, which should be defended and developed is the strengthening of spirituality-based education which will, in fact, strengthen the authenticity of humanity which is always imaged by divinity. ${ }^{14}$ Sufistic doctrine can be used as the ethical basis for the development of a more humanistic life while maintaining productivity in the midst of a modern lifestyle that produces injustice and social inequality. The functionalization of Sufi teachings is more urgent when appreciating the territory of this country hit by natural disasters due to mismanagement. The conflict sharpened in the political battle every time the change in party leadership and regional head elections began to take place throughout the country, making poverty and suffering of the people even worse. The poverty-stricken and victims of natural disasters are increasingly neglected when party elites and even religion are trapped in the struggle for material power. Sufi doctrine teaches how to liberate humanity from the trap of power and rich desires that make economic, political and religious leaders lose their sense of humanity.

The accusations of Sufism are the main cause of the weak social, economic and political ethos so that the majority of Muslims are classified as poor and have low education due to misunderstandings that define Sufi teachings, which clearly originate from the Kitabullah and al-Sunnah. Sufi teachings can be the ethical basis of the dynamics of social, economic and political life that are humanistic and just in the global world, if interpreted as humanitarian praxis. The root of Sufi ethics is the willingness of humans to place material and worldly dynamics (social, economic, political) as a vehicle for achieving higher levels of life (maqam). For Sufis, social, economic and political life is not the final goal, but the ladder for life is higher. This is the meaning of suluk teachings as a way to reach ma'rifat; ma'rifat is the highest gift about the nature of the dynamic life of nature and

${ }^{14}$ Ali Harb, Nalar Kritis Islam Kontemporer (Yogyakarta: IRCiSoD, 2012), 76. humans. The futuristic ma'rifat gift creates human beings who are good at seeing the causal laws of history and various possible events in the future.

Capitalistic and political greed that tend to be corrupt are born due to economic and political behavior-oriented only to the acquisition of finalists wealth. The idea of Imam al-Ghazali is often used as a reference to the rejection of involvement in historical, economic and political dynamics in the zuhd dan faqr doctrine. That teaching for al-Ghazâlî means laying down economic and political activities for devotion to God, not rejecting or running away from empirical life. As Biyanto stated, a Sufi cannot stand idly by, but must actively work and interact with the community. ${ }^{15}$ This is transcendence and radicalization in philosophical thought. Such a process will foster awareness about self, the reality of the universe, and God.

Islamic spirituality or Sufism has other aspects that are reflected in the expression of contemplating the beauty of mankind is the media to reflect on the beauty of God. The spirituality of Islam or Sufism seems to have a strong significance for modern Western societies that are beginning to feel the inner drought and now their efforts to fulfill it are increasingly urgent. They search, both for Christian and Buddhist teachings or just adventure back to nature as 'uzlah' from boredom due to the twist of scientific-technological society. In a situation of confusion like that, Islam is still not seen as an alternative search, because Islam is seen from its legalistic-formalistic side and much forms an obligation for its followers and does not have spiritual wealth.

\section{The Obstacles to Sufism in the Multicultural and Global Era}

Islam is a religion that strongly emphasizes the balance between Shari'a as God's law and tarekat as a spiritual path which is often called Sufism.

\footnotetext{
${ }^{15}$ Biyanto, "The typology of Muhammadiyah Sufism: tracing its figures' thoughts and exemplary lives", Indonesian Journal of Islam and Muslim Societies 7, no. 2 (2017): 222.
} 
If the Shari'a is called the exoteric dimension of Islam which deals more with the outward aspects, then the tarekat is the esoteric dimension of Islam which deals more with the inner aspect. External barriers in the form of modernization and advancement in science and technology have now succeeded in tearing up national borders, penetrating cultural walls and stretching networks of international relations closer. The progress of science and technology implies its influence so widely in systems thinking that is related to religious problems, and we are required to be able to think systematically and rationally. There is hardly one culture today that is pure without being influenced by the modernization and progress of science and technology.

Internal barriers include the attitude of Muslims who regard Sufism as a cause of the decline. Sufism is only appropriate for the elderly and those who are approaching death. Some of them are interested in Sufism but only in the aspect of their thoughts (philosophical Sufism), so Sufism is only a matter of conversation in seminars but is not reflected in personal, family or community life. Conversely, there are those who are only concerned with the amaliah aspect (tasawuf 'amali) and no longer pay attention to aspects of his thinking. There is a tendency to separate between Sufism and fiqh because between Sufism and fiqh there can be conflict. ${ }^{16}$

Sufism traditions that should be anticipatory, dynamic and creative lose more their original nature and face every problem. Sufism is more reactive, there is even a tendency to isolate (isolative). This isolative attitude is exacerbated by avoiding the world as a result of mistakes in understanding Sufism, the call for hubuddun-ya has been misinterpreted by the attitude to avoid the world. ${ }^{17}$

In the current era of modernization and globalization, Westerners have succeeded in

\footnotetext{
${ }^{16}$ Ahmad Bangun Nasution dan Rayani Hanum Siregar, 58.

${ }^{17}$ Kautsar Azhari Noer, Tasawuf Perennial, Kearifan Kritis Kaum Sufi (Jakarta: Serambi Ilmu, 2003, 52).
}

developing their logical abilities (intellectual intelligence) to achieve rapid progress from time to time in various fields of life, including in the fields of science and technology, which progress cannot be stopped but it is far from the spirit of religion so that those born are secular science and technology. ${ }^{18}$ Humans race each other for success in the material field, social, politics, economy, rank, position, position, power and so on, but when they are at the peak of success then their souls experience shocks and they are confused as to what all this is. Why can it happen that way? It is because their souls are in the emptiness of spiritual values because they do not have a clear orientation in treading life in the world.

Sayyid Hossein Nasr considers that the alienation of Westerners is because of the modern civilization that they built from the negation of the fact of spiritual gradually in human life. ${ }^{19}$ As a result, humans forget about their existence as 'abid (servant) before God because they have been cut off from the roots of spirituality. This is a phenomenon of how modern humans have acute spirituality. In turn, they tend to be unable to answer various problems in their lives, and are then caught up in the void and meaninglessness of life.

The knowledge that is only produced by psychic awareness (not spiritual) and ratio is only fragmented and temporary. The knowledge that will bring happiness and peace will only be achieved if someone has opened his eyes, or his intellectual vision, then always holds a spiritual ascent (suluk) towards the center through the spiritual wisdom of religion. ${ }^{20}$ Such a person, even though he lives within the limits of space and time and works with his fragmental scientific discipline, but he will be able to understand the secrets of nature so that he can manage it.

\footnotetext{
${ }^{18}$ Evelyn Underhill, Mysticism: The Preminent Study in the Nature and Development of Spiritual Conciousness (New York: Image Books Doble Day, 1990), 174.

${ }^{19}$ Seyyed Hossein Nasr, 8.

${ }^{20}$ Simuh, Tasawuf dan Perkembangannya di Dunia Islam (Jakarta: Rajawali Press, 1996), 107.
} 
Meanwhile, the eyes of his heart made him realize that the nature he managed was a fellow creature of God who signaled the Creator. Modern humans have created a situation in such a way that runs without control, so they fall into a pinched position which in turn not only leads to environmental destruction but also human destruction.

Modern science removes knowledge about cosmology from its discourse although cosmology is "sacred science" which explains the relation of the material world to revelation and metaphysical doctrine. Humans actually according to nature cannot escape from spiritual life because indeed the human self consists of two elements, namely physical and spiritual, human beings besides physical beings as well as non-physical beings. In humans, the demands of physical and spiritual needs must be fulfilled simultaneously and in balance, physical needs can be fulfilled with material things while spiritual needs must be fulfilled with spiritual things such as worship, dhikr, ethics, and other good deeds. If the two things cannot be fulfilled fairly, then human life can be sure to experience drought and voidness, even if it is possible to experience stress.

One criticism aimed at modern science and technology from an Islamic point of view is that modern science and technology are only valid methodologically, but are poor in moral and ethical terms. The view of modern society, which relies on the achievements of science and technology, has marginalized the transcendental Divine dimension. As a result, the life of modern society is losing one of its most fundamental aspects, namely spiritual aspects. ${ }^{21}$

Allegations and criticisms of Sufism are indeed often unwarranted. These accusations and criticisms usually come from groups who do not understand Sufism comprehensively and

\footnotetext{
${ }^{21}$ Kahlil Gibran, Al-Arwah Al-Mutamarridah, Jiwa-jiwa
} Pemberontak (Yogyakarta: Navila, 2010), 26. do not see it from the Sufi perspective itself. ${ }^{22}$ Theologically, Sufism actually has a strong doctrinal basis in al-Qur'ân and al-Sunnah. Sufism has a stronger root in al-Qur'ân than the Shari'ah. Sufism which is considered a symbol of humility and passivity is also a conclusion that is over-generalization, because in many cases in the Muslim world Sufis and followers played an active role in fighting against the colonials. In Indonesia, several tarekat were groups of people who were feared by the Dutch colonial government because of the "rebellion" movements they carried out.

It should be noted and this is a historical fact that in North Africa, Sudan in 1943 emerged famous Sufi movements, the Ashiqqa and Marabaouts (al-Murabbithun) sects, which had a major role in political arcades against the occupation. The Sufis could behave abusively and act as reformers and top leaders. ${ }^{23}$ During the dynasty of Saljuk, Sufism also served as a protest movement against tyranny of power. They criticized an intimidated cleric with the ruler (who by al-Ghazâlî was referred to as the ulama'su'). Sufism also rejects aristocratic views. ${ }^{24}$

This is a fact that Sufi practices cannot only be assumed as zuhud and zikr worship in the sense of ansich ritual. In modern conditions and the current technological era, Sufi practices are still relevant and even very necessary, noting that their understanding is not as narrow as that understood by some people (alienating themselves from mass communication). ${ }^{25}$ But it must be explained in a contextual sense. And we can see sociological symptoms, that in the Suryalaya Islamic Boarding School in West Java (which is famous for the Tareqat Islamic

\footnotetext{
${ }^{22}$ Abdullahi Ahmed Anna'im, Islam dan Negara Sekular, Menegosiasikan Masa Depan Syari'ah (Bandung: Mizan, 2007), 82.

${ }^{23}$ Donald E. Smith, Religion and Political Development (Michigan: Little, Brown, 1970), 135.

${ }^{24}$ John L. Esposito, Islam and Politics. Second Edition (New York: Syracuse University Press, 1984), 304.

${ }^{25}$ Amin Syukur, Menggugat Tasawuf-Sufisme dan Tanggung Jawab Sosial Abad 21 (Yogyakarta: Pustaka Pelajar, 2002), 151.
} 
Boarding School), a cultural movement has taken place in the form of agriculture, cooperatives and the environment. Even the Islamic boarding school gets a lot of attention from scientists and the government itself. Non-medical treatment of mental illness (drugs etc.) using a formula known as theikrullah formula is a distinctive feature for Abah Anom (nickname of the Kiai and his pesantren caregivers). Doesn't this form and reality change our picture of the Sufi world?

In this complex, modern life, where science and technology are so sophisticated and elaborate to almost all regions of the world when humans must dwell on the problems of life that are all materialistic. The relationship between humans in modern times also tends to be "impersonal", not familiar with one another. Traditional people who are fun are eroded by waves of modern society that are potent. This phenomenon makes people lose their identity. Such conditions also require humans to really be able to survive and control themselves, to then remain strong in personality. ${ }^{26}$

As a result of overestimating the ratio, modern humans are easily afflicted with spiritual emptiness. The rapid progress in the field of science and technology is felt to be unable to fulfill basic human needs in aspects of transcendent values, which can only be extracted from the source of divine revelation. ${ }^{27}$ Berger asserts that supra-natural values have vanished in the modern world. The loss of boundaries that are considered and believed to be sacred and absolute, making modern humans only circle in a relative world, especially the system of values and morality that they build. Thus, modern humans who ignore their most basic spiritual needs cannot find inner peace, which means there is no balance in themselves.

\footnotetext{
${ }^{26}$ Azyumardi Azra, "Neo-Sufisme dan Masa Depannya", in Muhammad Wahyuni Nafis (Ed.), Rekonstruksi dan Renungan Religius Islam (Jakarta: Paramadina, 1996), 187.

${ }^{27}$ Murtadha Muthahhari, Menapak Jalan Spiritual Sekilas Tentang Ajaran Tasauf dan Tokoh-tokohnya (Bandung: Pustaka Hidayah, 2006), 41.
}

This situation will be further aggravated, especially if the pressure on material needs increases so that the balance will be increasingly damaged. Realizing that modernization and globalization turned out to be unable to meet human spiritual needs, it is not surprising that humans are now abuzz to return to religion which indeed functions, among other things, to give meaning to life.

This understanding can provide concrete evidence when looking at phenomena that occur in the midst of urban society today. There are Sufism institutions which have no direct roots to the tarekat and are held in mass as well as commercial, for example, dzikir together, repentance, dhikir therapy. The face of Sufism in other forms is done and is very salable Emotional Spiritual Question (ESQ) under the leadership of Ari Ginanjar. ${ }^{28}$ Because it entered the industrial sphere and came into contact with commercialism, Sufism seemed to be a tool to promote religious behavior that was cathartic. Repentance, a window into Sufism became the arena of remorse that was shown. Dhikr was presented together and guided, which was forced to become as if it were special 'and prayed with tears. If not careful, this pattern will fall into pseudo-Sufism. Sufism only prioritizes spectacle rather than the substance of appreciation and internalization in everyday life.

Presumably, this is more specific in contemporary Sufism, a new form that occurs in the midst of modern society. If many modern times are faced with the enthusiasm to return to a more positive form and purity of religious teachings, then contemporary Sufism is a shift in the model from the individual nature of Sufism to the mass region..$^{29}$ This departs from failure in the imaging and emptiness of the soul, at least in the masses there is a recognition of the individuals who enter the worship group. The mass region is

\footnotetext{
${ }^{28}$ Ary Ginanjar Agustian, Membangaun Rahasia Sukses Kecerdasan Emosi dan Spiritual (Jakarta: Arga, 2005).

${ }^{29}$ Ahmad Najib Burhani, "Tarekat" Tanpa Tarekat Jalan Baru Menjadi Sufi (Jakarta: PT. Serambi Ilmu Semesta, 2002), 103.
} 
a community that has a mass communication and information technology container. Sufism entered into a part of the living device with a new face that fits the tastes of the times. ${ }^{30}$

Thus, the challenge of Sufism is the actual form of the religious style of modern society in a multicultural and global era. If not careful, or wrong in teaching and the application will bring the form of forgery of Sufism. Or more extreme, contemporary Sufism teachings that come into contact with the Sufis style, are only taking the spirit that is not intact from conventional Sufism known so far. If we understand the Sufis style, as if it only leads to the world of Sufism, it does not enter into the realm of Sufism in total.

The Sufism of the global era places the values of Sufism into small or even become material from technology, and its authenticity is still doubtful. It only becomes a small part of advanced technology, not as a subject of progress. Nevertheless, it is still based on the al-Qur'ân and al-Sunnah, but putting forward packaging rather than essence. They are involved in the world of Sufism in the global era, but even so, they continue to try and explore and feel and acknowledge that they have begun to enter the Sufis. Certainly, there will not be able to be the soul of Sufism that has ever existed in the past to be picked up totally without knowing the teachings and doctrine of Sufism in full. Moreover, only picking up important parts and making it as material from what is commercialized as commodity material to a modern and multicultural society.

Although there are indirectly classical and conventional roots, they actually learn deeply about each teaching and practice it in everyday life. There is a longing for a modern and multicultural society to return to life at the root of

${ }^{30}$ Syafiq A. Mughni, "Tradisi Zuhud dan Sufisme dalam Muhammadiyah" in Hasnan Bachtiar (ed.), Diskursus NeoSufisme Muhammadiyah: Genealogi, Konstruksi dan Manifestasi (Malang: Universitas Muhammadiyah Malang Press, 2015), 241. religious culture that is ahead of religious spirits. Not just an actual formality but also has a deep meaning for everyday life. But if we look further, we should continue to be evaluated because Sufism is in contact with industries that tend to be double-edged. Apart from the pluses and minuses of teaching, also the patterns and portraits of his life which almost led to the pseudo-Sufism, his enthusiasm and influence brought an important meaning to Islam in the midst of society. Even more modern and multicultural society really longs for the treasures of religious life.

\section{Conclusion}

The progress of science and technology in this multicultural and global era must be useful to recognize the creation, majesty and greatness of God, so that it can encourage people to get closer to Him. But in reality, modernization only satisfies physical needs, even though humans will remain nervous as long as their inner and divine needs are not fulfilled. In fact, the values of Sufism which is spiritual conditioning in filling the emptiness of the human soul, are expected to obey the people to implement the rules of Shari'a, so that the appreciation of religion at the level of essence and wisdom does not slip into the abyss of shirk and khurafat.

Thus, its existence in the midst of society proves that Sufism is a separate part of a community's life; as a movement and religious belief such conditions cause people to remain steadfast, patient and not easily blown away by trials that will deflect the brink of destruction. For this reason, Sufism must be one of the most important alternatives in overcoming the problems of people's lives in the era of multiculturalism and globalization. So the presence of Sufism in the modern world is very necessary, in order to guide human beings to stay long and close to their Lord, and it can also be for people who were originally glamorous and who were happy to become ascetic people. 


\section{References}

Agustian, Ary Ginanjar. Membangaun Rahasia Sukses Kecerdasan Emosi dan Spiritual. Jakarta: Arga. 2005.

Anna'im, Abdullahi Ahmed. Islam dan Negara Sekular, Menegosiasikan Masa Depan Syari'ah. Bandung: Mizan. 2007.

Ayoub, Mahmoud. "Religious Pluralism and the Quran", available at http://iiit.org/ Research/ScholarsSummerInstitute/ TableofContents/ReligiousPluralism AndThe Quran/tabid/244/Default.aspx (30 April 2018).

Azizy, A.Qadri. Melawan GlobalisasiReinterpretasi Ajaran Islam. Yogyakarta: Pustaka Pelajar. 2003.

Azra, Azyumardi. "Neo-Sufisme dan Masa Depannya," in Muhammad Wahyuni Nafis (Ed). Rekonstruksi dan Renungan Religius Islam. Jakarta: Paramadina. 1996.

Biyanto. "The typology of Muhammadiyah Sufism: tracing its figures' thoughts and exemplary lives". Indonesian Journal of Islam and Muslim Societies 7, no. 2 (2017).

Burhani, Ahmad Najib. "Tarekat” Tanpa Tarekat Jalan Baru Menjadi Sufi. Jakarta: PT. Serambi Ilmu Semesta. 2002.

Esposito, John L. Islam and Politics. Second Edition. New York: Syracuse University Press. 1984.

al-Ghanimi, Abul Wafa'. Madkhal ilā Tașawwuf al-Islām. cet. III. Kairo: Darussaqafah Linasyr wattauzi’, 1983.

Gibran, Kahlil. Al-Arwah al-Mutamarridah, Jiwa-jiwa Pemberontak. Yogyakarta: Navila. 2010.

Hamzeh, A. Nizar and R. Hrair Dekmejin. "A Sufi Response to Political Islamism: Al-Ahbaash of Lebanon". International
Middle East Studies 28 (1996).

Harb, Ali. Nalar Kritis Islam Kontemporer. Yogyakarta: IRCiSoD, 2012.

Hashemi, Nader. Islam, Secularism, and Liberal Democracy: Toward a Democratic Theory for Muslim Societies. NewYork: Oxford University Press, 2009.

Mughni, Syafiq A. "Tradisi Zuhud dan Sufisme dalam Muhammadiyah" in Hasnan Bachtiar (ed.). Diskursus Neo-Sufisme Muhammadiyah: Genealogi, Konstruksi dan Manifestasi. Malang: Universitas Muhammadiyah Malang Press. 2015.

Muthahhari, Murtadha. Menapak Jalan Spiritual Sekilas Tentang Ajaran Tasauf dan Tokohtokohnya. Bandung: Pustaka Hidayah. 2006.

Nasr, Seyyed Hossein. Science and Civilization in Islam, USA: Harvard University Press, 1968. Accessed from https://scholar. google.co.id/citations? user $=$ S9yBp OMAAAAJ\&hl.

Nasution, Ahmad Bangun dan Rayani Hanum Siregar. Akhlak Tasawuf. Jakarta: PT. Raja Grafindo Persada. 2013.

Noer, Kautsar Azhari. Tasawuf Perennial, Kearifan Kritis Kaum Sufi. Jakarta: Serambi Ilmu. 2003.

Saliyo. "Mencari Makna Hidup Dengan Jalan Sufi di Era Modern". Esoterik: Jurnal Akhlak dan Tasawuf 2, no. 1 (2016). Accessed http://dx.doi.org/10.21043/ esoterik.v2i1.

al-Sayyid, Ridwan. "Pluralism and Liberalism in Contemporary Islamic Thought”. In Abdou Filali Ansary and Sikeena Karmali (Eds.). The Challenge of Pluralism: Paradigms from Muslim Contexts. Edinburgh: Edinburgh University Press,2009.

Schimmel, Annemarie. Dimensi Mistik Dalam Islam. Jakarta: Pustaka Firdaus. 2002. 
Simuh. Tasawuf dan Perkembangannya di Dunia Islam. Jakarta: Rajawali Press. 1996.

Smith, E. Donald. Religion and Political Development. Michigan: Little, Brown, 1970.

Soleh, Moh. Agama Sebagai Terapi. Yogyakarta: Pustaka Pelajar. 2005.

Suyuti, Ahmad. Percik-percik Kesufian. Bandung: Penerbit Pustaka Hidayah. 2002.

Syukur, M. Amin. Tasawuf Kontekstual Solusi Problem Manusia Modern. Yogyakarta: Pustaka. 2003.
-----. Menggugat Tasawuf-Sufisme dan Tanggung Jawab Sosial Abad 21. Yogyakarta: Pustaka Pelajar. 2002.

Ubaedillah, Achmad. "Sufi Islam and the nation state: Darul Arkam movement in the post Suharto era of Indonesia”. Indonesian Journal of Islam and Muslim Societies 5, no. 1 (2015).

Underhill, Evelyn. Mysticism: The Preminent Study in the Nature and Development of Spiritual Conciousness. New York: Image Books Doble Day. 1990. 